\title{
AN EXAMPLE OF USING CAD SOFTWARE IN THE MODELING OF MINING EXCAVATIONS OF THE HISTORICAL SALT MINE "BOCHNIA"
}

\author{
AGH University of Science and Technology
}

Keywords: spatial visualization of mine, modeling of mining tunnels

\begin{abstract}
The development of information technologies has made the presentation of engineering objects in the form of spatial visualizations more common. This applies primarily to historical objects made available for tourism, which in practice increases their attractiveness to the recipients. Known from the literature, the pseudo-spatial (on the plane) studies of the historic "Wieliczka" Salt Mine are examples of masterpieces of engineering graphics, but they are one-time works, due to the technology of the model construction, as well as the complexity of the model and the number of details presented (after-exploitation chambers and tunnels). Today, CAD software programs (AutoCAD, Microstation) allow you to generate models of all kinds of objects, based on archival and present documentation of data from geodetic or photogrammetric measurements. The degree of model generalization depends on the number and accuracy of the data sources used. One of the popular programs in the field of engineering graphics is program AutoCAD from Autodesk, which was used for modeling, based on the cartographic documentation of the spatial model of the "Bochnia" Salt Mine's current state.
\end{abstract}

\section{PRZYKLAD ZASTOSOWANIA ŚRODOWISKA CAD W MODELOWANIU WYROBISK ZABYTKOWEJ KOPALNI SOLI „BOCHNIA”}

Słowa kluczowe: wizualizacja przestrzenna kopalni, modelowanie wyrobisk

\begin{abstract}
Abstrakt
Rozwój technologii informatycznych spowodował upowszechnienie sposobu prezentacji obiektów inżynierskich w formie przestrzennych wizualizacji. Dotyczy to przede wszystkim obiektów zabytkowych udostępnionych dla ruchu turystycznego, co w praktyce zwiększa ich atrakcyjność także w sferze odbioru. Znane z literatury fachowej opracowania pseudoprzestrzenne (na płaszczyźnie) zabytkowej Kopalni Soli „Wieliczka” stanowią swego rodzaju arcydzieła grafiki inżynierskiej, ale są to opracowania jednorazowe z uwagi na technikę budowy modelu, a także złożoność modelu oraz liczebność prezentowanych szczegółów (komór poeksploatacyjnych i chodników). Dziś programy środowiska CAD (AutoCAD, Microstation), pozwalają na generowanie modeli wszelkiego rodzaju obiektów na podstawie dokumentacji archiwalnej i aktualnej lub danych pochodzących z pomiarów geodezyjnych oraz fotogrametrycznych. Stopień generalizacji modelu uzależniony jest od liczebności i szczegółowości wykorzystanych źródeł danych. Jednym z popularnych programów z zakresu grafiki inżynierskiej jest program AutoCAD firmy Autodesk, który stanowił narzędzie opracowania na podstawie dokumentacji kartograficznej modelu przestrzennego Kopalni Soli „Bochnia” według aktualnego stanu.
\end{abstract}




\section{INTRODUCTION}

The development of mining cartography over the centuries has contributed to the creation of highly accurate maps of mining plants throughout the world. Also, in Poland, mining cartography experienced periods of the revival, modeled on the achievements of West European pioneers in the field of cartography (Agricola). An example of extremely valuable studies are maps of mining excavations of the "Wieliczka" Salt Mine, prepared in 1631-1638 by geometrician Marcin German, based on measurements of the geometry of the salt mine: Jan Brożek and Jan Gotfryd Borlach, illustrating the three existing operational levels bearing the signature by the author: ,image of Wieliczka salt mine: first, second and third" (from Latin Delineatio Prima, Secundae, Tertiae). A typical information carrier were copper boards (engravings), on which the copperplate technique (concave graphic technique) was applied with great care to the content. Later, a typical carrier of drawing data was paper (analog maps made using drafting techniques on durable material), which is widely used in all measuring departments of mines operating in Poland, which results from the recommendation of the "Regulation of the Minister of the Environment of 28 October 2015 on documentation of geological survey". Also, the Act on Geological and Mining Law of 2011 obliges every mining plant to compulsorily carry out geological survey documentation in the form of general reference and thematic maps, which should be periodically updated (the interval depends on the mineral and type of maps), and archiving completed documentations in the mine surveyor department. Cartographic documentation is the basis for safe and proper mining operations. It is the basis for the functioning of the mine and is the foundation material for the design of a new exploitation (access to a deposit, deck or field, aerological projects, plans of re-works, etc.) and for the safe maintenance of existing excavations. The thematic scope of mining maps for a given type of mineral, scale and group is defined in Poland by mining standards, supplemented individually by mine surveying departments with non-standard characters contained on the title cards of individual mining plants. The development and dissemination of CAD software programs and thematic overlays for semi-automatic or automatic drafting of surveying and geological documentation, its editing and updating has resulted in dissemination of numerical (digital) form of managing cartographic resource (Maciaszek et al., 2015), which was legally established in the Enactment of the Minister of the Environment on surveying and geological documentation. The advantage of this form is the accuracy of elements illustrating the course of mining tunnels, location of the accompanying devices, easy access to the content and database modification of such studies. Expansion of the cartographical base of mines by its spatial form is more and more often observed, which simplifies the process of map analysis and better affects the user's understandings. Thus, keeping a spatial map belonging to the group of thematic maps (according to the division included in PN-G-09000-1:2002) of any scale, whether in the form of classic studies (drawn using various types of views selected on the basis of intuitive "aesthetic sense") (Maciaszek et al., 2010), or a numeric map is not compulsory in Poland (optional nature of documentation). The reluctance of mines to implement three-dimensional documentations based on two-dimensional documentation results, because of the time-consuming nature of creating a spatial model of mining tunnels and the rate of the mining progress. This means that the existing cartographic (two-dimensional) documentation is a subject to only some modifications, resulting from the need for local mining works related to the protection of mining tunnels and their reconstruction and the process of liquidation in case of high degradation of the rock mass around the void or unprofitable maintenance of an excessively damaged mining tunnel of minimal historical value. The article presents the results of developing a spatial model of the mining excavations in the "Bochnia" Salt Mine made in AutoCAD based on general maps of existing exploitation levels provided by the measuring department.

\section{GEOMETRIC STRUCTURE OF THE MINE AND GEOLOGICAL DEPOSIT}

The "Bochnia" Salt Mine is the oldest mining plant in Europe, operating continuously since 1248 (according to Freudenheim and Migdas, 2006) or since 1251 (according to Fischer, 1941). Discovery of the deposit was a consequence of works related to the deepening or reconstruction of the salt wells operating at that time. The great importance of salt for the country's economy is evidenced by the fact that in 1253 Bochnia received city rights under the Magdeburg Law. Originally, the exploitation covered surface layers at a depth of 14-45 m 
in outcrop areas of the deposit, precisely in today's city center zone (between the Regis and Gazaris shafts). Over time, the exploitation went deeper, moving west.

Bochnia deposit has a shape of a lens (with significant folding of the deposit and a steep slope) with a length of about $3.5 \mathrm{~km}$ (latitudinally) and a width of several dozen to $200 \mathrm{~m}$ (meridional). This results in the simplicity of the morphological layout of the excavations. The deposit at each exploitation level was made available through individual tunnels, so-called drifts and the accompanied with numerous cross crosscuts (perpendicular to the drifts) in intervals of 30-100 m (Kortas et al., 2004). The depth of salt deposits ranges from several meters to $80 \mathrm{~m}$ (Kortas et al., 1993). The deposit itself is formed in the form of two main folds (anticlines - Pitera, Cyran, 2008):

- Bochnia anticline - passing directly under the city;

- Uzbornia anticline - located south of the city.

The spatial layout of the "Bochnia" Salt Mine (number of tunnels and chambers, their shape and development directions) reflects the geometry of the salt deposit.
Like most historical mines in Poland, Bochnia experienced economic ups and downs over the centuries. Until 1561 (the date of the outbreak of the great fire), the Bochnia mining company was extracting up to 4,500 tons of salt a year, while maintaining a constant number of saltworkers, i.e. 115. The fire contributed to the collapse of the city and the mining plant to such an extent that at the beginning of the 18th century even the salt measures collapsed. The development of mining technologies and the demand for raw materials contributed to reactivation of mining activities in Bochnia in the second half of the 19th century and modernization of the mine. This resulted in an increase in production capacity. Exploitation using traditional methods was carried out until 1967, when the pure salt deposits were completely depleted. In order to maintain production potential, a decision was made to extend the exploitation to lower batches of residual unsupported salt (contaminated) by the wet method (leaching), resulted from demand for this raw material to be developed in chemical industry of this part of the country. Symbolic exploitation of salt was carried out until 1990, when the decision to liquidate the plant was made.

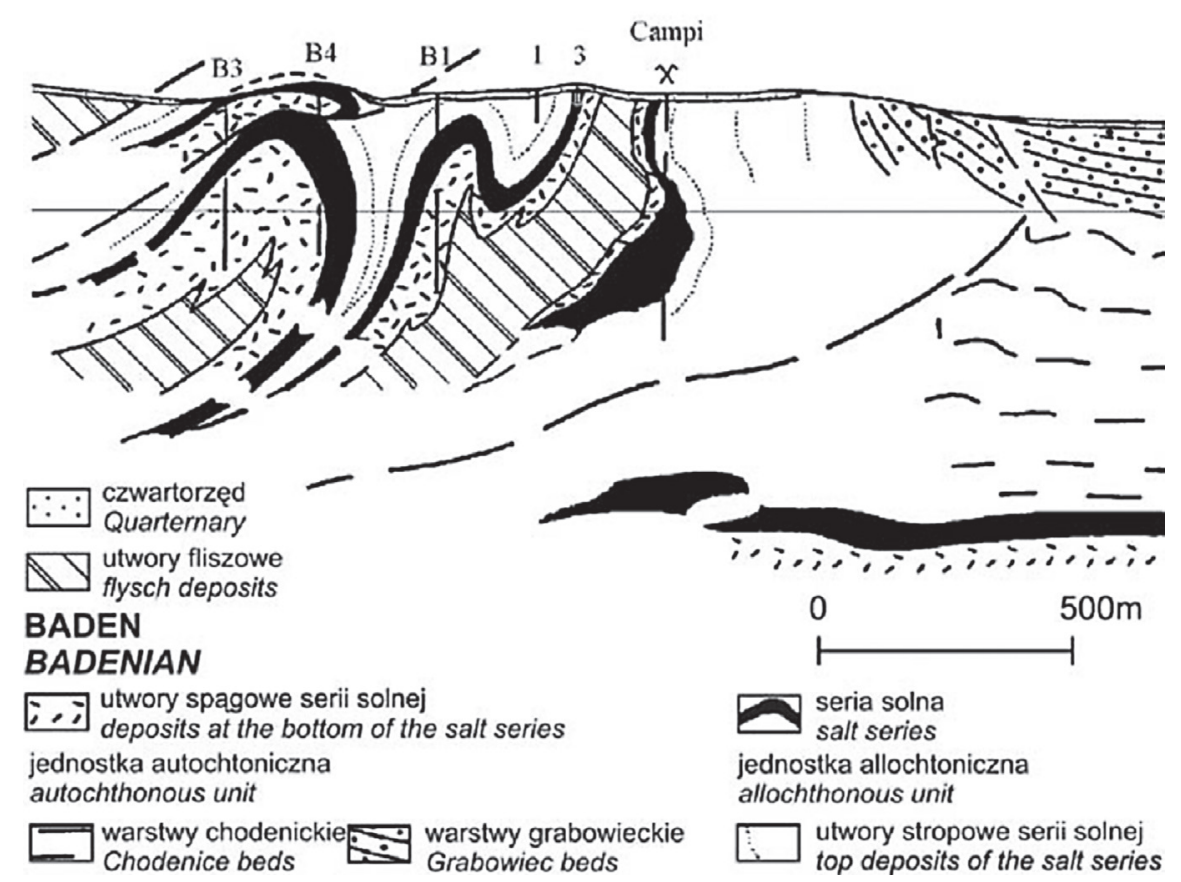

Fig. 1. Cross-section through the rock mass in the vicinity of the Campi shaft (according to Garlicki, 1968) Rys. 1. Przekrój przez górotwór w sąsiedztwie szybu Campi (według Garlicki, 1968) 
At the same time, some excavations located in the central part of the mine (at higher levels) with high historical, educational, didactic and health-resort values were transformed into a recreational-sanatorium and tourist facility (underground tourist route). From the thirteenth to the twentieth century, all levels of exploitation were made available with five shafts, i.e. Trinitatis, Campi (main mining shaft), Regis, Sutoris and Floris, as illustrated in Figure 2. The above-mentioned shafts constituted a link between the individual levels (maximum 10 levels distributed on average 20-30 m connected by the Campi shaft) and the surface of the area. In total, the mine consists of 11 exploitation levels, with only Campi shaft is connected with 10 of them. The lowest level is connected to the higher level by a blind shaft (Fig. 2). According to Kortas (2004) the beginning of exploitation was based on the exploitation of edible salt (manual mining) in the upper zone of the deposit with thin layers falling very steeply. Stair and ceiling system with dry filling, leaving voids in the form of narrow chambers, is chosen in the Bochnia mine, because of the complicated lithostratigraphic profile of the salt deposit. Over time, the development of mining methods has led to modification of methods of drawing mineral deposits. In the lower parts, salt was mined with explosives using a tunnel system with stair-ceiling, fully filling voids with contaminated salt. Partial or total liquidation of excavations with very irregular geometry and a limited set of data on the actual sizes and their shapes, do not allow for full reconstruction of the geometry of most of the previously existing and preserved to this day voids. The title card of the mining maps of the "Bochnia" Salt Mine shows that the maximum number of active levels in the mine's history was 16 (today only 9) with $4300 \mathrm{~m}$ of operational tunnels for tourists (without shafts).

Therefore, based on current surveying documentation, it is possible to prepare a model, reflecting only the generalized image of mine infrastructure preserved to this day. The mining practice in Bochnia showed that the chambers where security works were carried out, were transformed into a narrow tunnel ensuring continuity of communication between various regions of a given operating level. The plasticity of the salt layers, building the rock mass, led to self-liquidation of many voids. Also, in filled excavations due to their gradual crushing or in a steeper chamber profile due to convergence of both sides, a complete liquidation was carried out, which facilitated re-exploitation of the salt deposit in these zones. Despite a very complicated geometrical arrangement of the deposit and the complex forms of the chambers, the adopted filling system and control of these works protected the mine against spectacular collapses. Such situations were very rare in Bochnia, unlike the neighboring Wieliczka Salt Mine, although in the 20th century, a salt leaching system was implemented at lower levels.

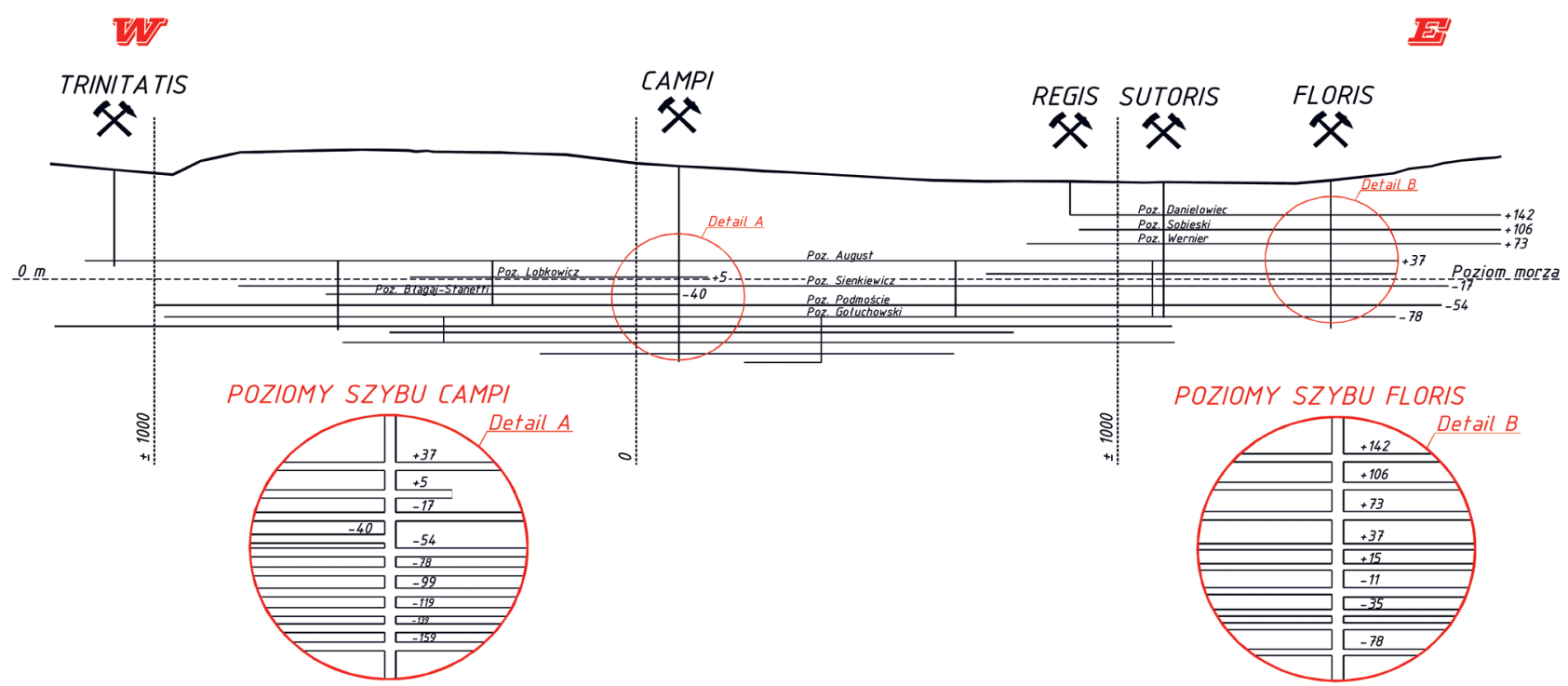

Fig. 2. Diagram of operating levels in the "Bochnia" Salt Mine (according to Poborski, 1952)

Rys. 2. Schemat układu poziomów eksploatacyjnych w Kopalni Soli „Bochnia” (według Poborski, 1952) 
Security works of the excavations, carried out during and after the end of exploitation, led to quantitative and qualitative reduction of the size of the mine infrastructure. In 2004, only 81 chambers were available at the depths from $70 \mathrm{~m}$ ppt (Level Danielowiec) to $448 \mathrm{~m} \mathrm{ppt}$ (Level XII) with the total area of $421,000 \mathrm{~m}^{2}$ and volume of 3.12 million $\mathrm{m}^{3}$ (according to J. Siembab - state for the year 1987). Lowest levels, where exploitation was carried out by salt leaching method, are completely liquidated and the lack of data does not allow their reconstruction.

\section{ANALOG SPATIAL MAP AS A PROTOPLAST OF TODAY'S STUDIES}

Analog spatial maps belong to group of thematic underground mine maps, and due to their form they are often an excellent base for other maps, e.g. transport, ventilation, drainage (Maciaszek, Gawałkiewicz, 2001). Using the methods of spatial projection (axonometric, affine, vector, central projections, etc.), flat forms of post-mining voids (rectangular projections of excavations) obtain a pseudo-three-dimensional form with a high degree of measurability, visibility and transparency of the study. In addition, spatial maps create the possibility of enhancing certain details, which on flat maps are limited due to the degree of generalization. The right choice of method for the geometrical characteristics of mine infrastructure can guarantee better measurability of the elaboration and exposure of details, especially important for achieving the set goal. Research conducted under the direction of J. Siembab (1980) allowed the determination of the degree of suitability of the projection method to local geological and mining conditions (structures: reservoir, mixed or geometric). Unfortunately, preserved pseudo-spatial studies of the mines (e.g.,. the "Wieliczka" Salt Mine) created mainly in the 1980s, despite being masterpieces of mining cartography, have one significant drawback, i.e., they are usually unmodifiable drawings, which means that they have the character of one-time measuring documentation (Maciaszek, Gawałkiewicz, 2001). Today, the development of CAD computer software (vector drawing) guarantees the simplification of drawing procedures and allows you to keep 3D documentation in such a way that it is possible to update the study (remove objects or their fragments, add new map elements or modify existing ones, and carry out transformations). In the world literature there are more and more spatial studies of underground mines drafted in CAD software. This is due to the need of mining plants for the integration of many data from the field of: geodesy and surveying (course of excavations in space, land-use of mining), geology (tectonics, deposit boundary), mining (aerology, deposit exploitation projects) in order to increase the company's efficiency and to manage the mining process properly. Excellent examples are:

- Skroska Iron-nickel mine in Albania (Shehu, Lipo, 2016);

- Belmont Emerald's mine in Brazil (Lucas et al., 2015);

- Pyhäsalmi copper mine in Finland (Kohonen et al., 2019);

- Gold Field's South Deep gold mine in South Africa.

In Poland, this type of study, together with the analysis of the way spatial data is presented, was prepared for the historic "Wieliczka" Salt Mine (d'Obyrn, Tajduś, 2017) and the historic crystalline limestone mining plant in Ciechanowice (Wajs et al., 2018).

\section{NUMERICAL SPATIAL MAP}

Digital map as a cartographic documentation (with the status of optional elaboration) is a three-dimensional image of objects or the physical surface of the terrain, built in a way enabling automatic or semi-automatic design and building of informational systems based on elements on this map. Due to the fact that analog or digital maps (thematic) are derivatives of basic maps, the source of their creation can be (according to PN-G-09000-3: 2002):

- data from geodetic and photogrammetric direct measurements;

- cartographic archival (historical) works;

- data from mine supervisors, i.e. foreman sketches prepared for endangered underground facilities, where geodetic and photogrammetric measurements cannot be made (infarction, flooding of the excavation).

Three-dimensional mine maps may differ significantly. This is due to the applied graphical-computational algorithms and the method of obtaining information from the field of geometric parameters, such as: the surface of the excavation in a projection on a horizontal 
or vertical plane, the shape and area of any cross-section through the model. In practice, the qualitative and quantitative form of the database determines the possibility of constructing a specific three-dimensional model, i.e. to choose from: edge (skeletal), surface (shell) or solid (sliced or defined by adjacent cuboids or prisms modeling the geometric form of the excavation). Thus, the use of a specific form of source data allows you to generate models, such as:

- simplified (generalized) model based on floor projections of chambers and tunnels (Maciaszek et al., 2010) and knowledge of the average height of the excavation or part of it;

- complex - based on huge sets of spatial data acquired by modern geodetic measuring techniques (electronic tachymetry, laser scanning) or photogrammetric.

\section{NUMERICAL SPATIAL MAP OF THE BOCHNIA SALT MINE}

The use of three-dimensional space in the process of visualization of mining excavations allows you to fully display the geometric characteristics of the mine. To construct a three-dimensional model of the underground infrastructure of the "Bochnia" Salt Mine, digital (in * .bmp format), two dimensional maps of individual mining levels were developed in the local coordination system "Bochnia" (base mine coordination system with possibility of transformation into the PL-2000/7 system) and altitude system of Kronsztadt. Therefore, the 3D modeling stage had to be preceded by digitizing the level maps to the vector form (levels: August, Błagaj-Stanetti, Danielowiec, Gołuchowski, Lobkowicz, Podmoście, Sienkiewicz, Sobieski, Wernier and Dobosz level). Spatial model in the form of a simplified solid model while maintaining the contractual (typical) heights of chambers and tunnels has been chosen. The form of input data determined the choice of construction method for individual tunnel fragments. Therefore, a model was adopted based on flat outlines of excavation or cross-sections, i.e. tunnels and chambers, to 3D form by pull or press function with generalized heights of individual voids. The advantage of the simplified model by creating solids of excavation based on its horizontal projection (floor projection) is the small file size. For the presented model, the file size (1 file \# BOCHNIA.dwg) is only $13.7 \mathrm{MB}$, and the data structure allows for smooth rotation of the model. In addition, this way of constructing $3 \mathrm{D}$ excavations gives full cartometrics of the mine model horizontally (XY plane), which means that each measured horizontal distance between excavations located at different levels is a distortion-free distance. When determining vertical distances, only readings between floors located at different levels are actual values.

The modeling of Bochnia Salt Mine was prepared in AutoCAD while maintaining the color of the tunnel's set in accord with PN-G 09004: 2005, cross-sectional geometry of typical corridor headings (rectangular or semi-elliptical cross-section), and elevations of pavements and chambers. Considering the safety of touristic and historically and environmentally attractive areas (large volume, shape resulting from the system of exploitation), activities have been carried out for years to liquidate voids that were classified as low historical and educational value. Additional determinants of the decision by the mine authorities on further maintenance of the excavations or their liquidation (partial or total) are determined by constructional and geotechnical expertise analyzing actual technical condition of the voids, including the analysis of costs required for eventual security maintenance and adaptation to non-mining purposes (expansion of the underground tourist and sanatorium areas) and assessment of the degree of negative impact on nearby and operational excavations. The cartographic documentation of individual mining levels presents the outlines of active tunnels (with designation of the type of sets), closed tunnels (propped) and tunnels whose outlines have been transferred to a map from archives preserved in archives of geological and mine survey department (blue line). Picture of the spatial model of the "Bochnia" Salt Mine including:

- active (utilized) tunnels, which cross-section shape and colors have been assigned by the Ostwald scale in relation to the type of mining construction (steel, i.e. arched flexible ŁP - Figure 3a; wooden Figure 3b; without set - Figure 3c), - vertical tunnels (shafts) - gray color - Figure 3c,

- liquidated tunnels - propped (green), marked on maps in a way that allows recreating the geometry of the void along with their proper location in $3 \mathrm{D}$ space - Figure $3 \mathrm{~d}$,

shown in Figure 4 (677 objects in total) with an illustration of a fragment of the central part of the mine (de- 
a)

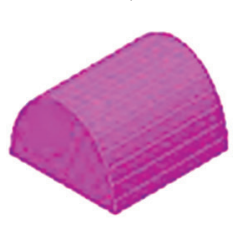

b)

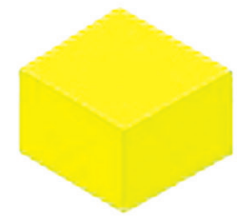

c)

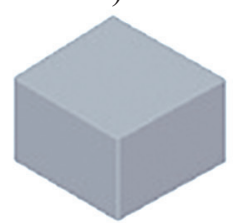

d)

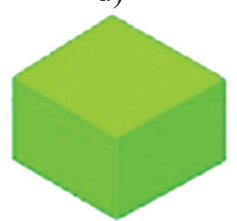

Fig. 3. Adopted geometry and colors of individual models of excavations of the "Bochnia" Salt Mine $\mathrm{a}-€ P$ steel set, $\mathrm{b}$ - wooden set, $\mathrm{c}$ - without set or concrete set (shafts), $\mathrm{d}$ - liquidated tunnels of a certain geometry

Ryc. 3. Przyjęta geometria i kolorystyka poszczególnych modeli wyrobisk Kopalni Soli „Bochnia”

$\mathrm{a}$ - obudowa stalowa $Ł P, \mathrm{~b}$ - obudowa drewniana, $\mathrm{c}$ - brak obudowy lub obudowa betonowa, $\mathrm{d}$ - wyrobiska zlikwidowane o określonej geometrii

tail), as in Figure 5. The study did not include historical excavations with insufficiently documented geometry (blue dashed line on mine maps). This applies i.a. lack of information about elevation of ceiling or floor, average or maximum height of the tunnel, cross-sectional shape, etc.

Due to the limited amount of information (only models of sidewalk and chamber excavations), the study did not require any complex delamination of the drawing. Also, the small number of available mining levels did not imply the need to build a more complex file structure, i.e. detailing the delamination in terms of height and position of a specific excavation (optionally, this can be done at the stage of model modification).

The spatial development of the mine using simplified excavation models gives the opportunity to determine the approximate cubic capacity of underground voids, which allows you to update the morphometric database of J. Siembab from 1987. The analysis of the morphometric parameters of excavations allowed to de-

Table 1. Total volume of given post-mining excavations of "Bochnia" Salt Mine

Tabela 1. Zestawienie objętości wyrobisk poeksploatacyjnych poziomów udostępnionych Kopalni Soli „Bochnia”

\begin{tabular}{|l|c|}
\hline \multicolumn{1}{|c|}{ Excavation type } & Total volumes in $\left[\mathbf{m}^{3}\right]$ \\
\hline With wooden set & 52522 \\
\hline With steel set $Ł P$ & 34606 \\
\hline Shafts & 13875 \\
\hline Without set & 39701 \\
\hline Liquidated (developed) & 62170 \\
\hline Sum total & $\mathbf{2 0 2 ~ 8 7 4}$ \\
\hline
\end{tabular}

termine the approximate volume of existing post-mining and liquidated cavities, for which range of data enabled the construction of 3D solid models with their height and location. The results of the analysis are shown in Table 1.

\section{SUMMARY}

Modern cartographic techniques based on the CAD software allow the creation of various forms of cartographic documentation in accord with applicable law. The mine map itself, whether it's flat or three-dimensional, is a factor facilitating the integration of many projects implemented during mine operations to guarantee the safety of people and underground infrastructure.

The presented simplified 3D model is a typical study, widely used all over the world in a situation of limited access to detailed spatial data (mines: Skroska in Albania and Belmont in Brazil). It is a foundation for further works on detailing selected parts of the mine using longitudinal section and cross-sectional methods commonly used at mines, as well as most advanced and modern measurement technologies available today, e.g. laser scanning. The prepared three-dimensional model of the mine is not a database development. It is a base model presenting the spatial layouts of mining excavations with designation of type of set, which results from quantitative and qualitative limitation of analog map data.

Despite the generalization of excavation heights, such a development of the Bochnia mine may be in the future a carrier for more detailed information related to excavation devices (location of the devices and machineries), phenomena accompanying exploitation (otherwise mining hazards) and constitute as an integral ele- 
KHULGUN OCHIRSUKH

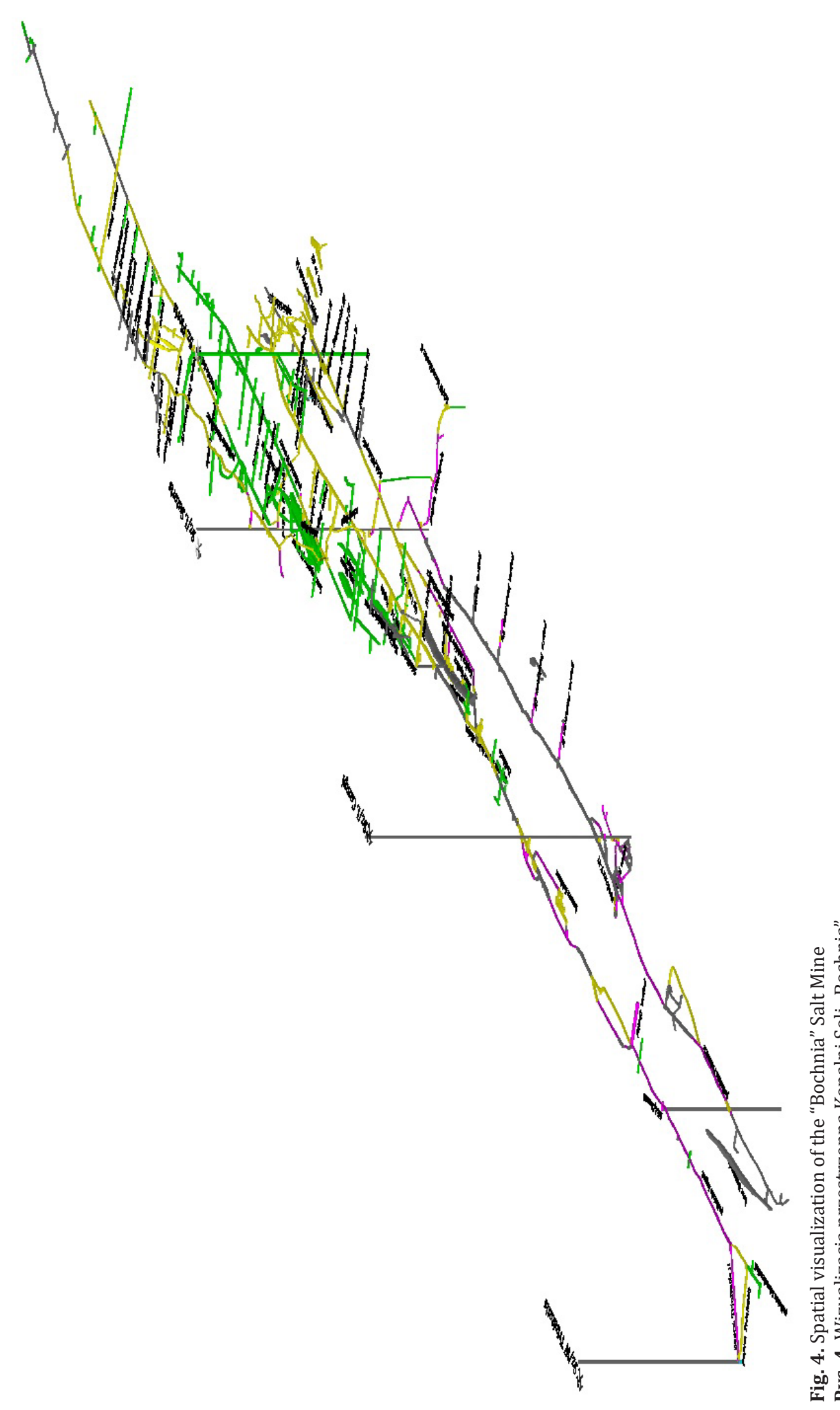




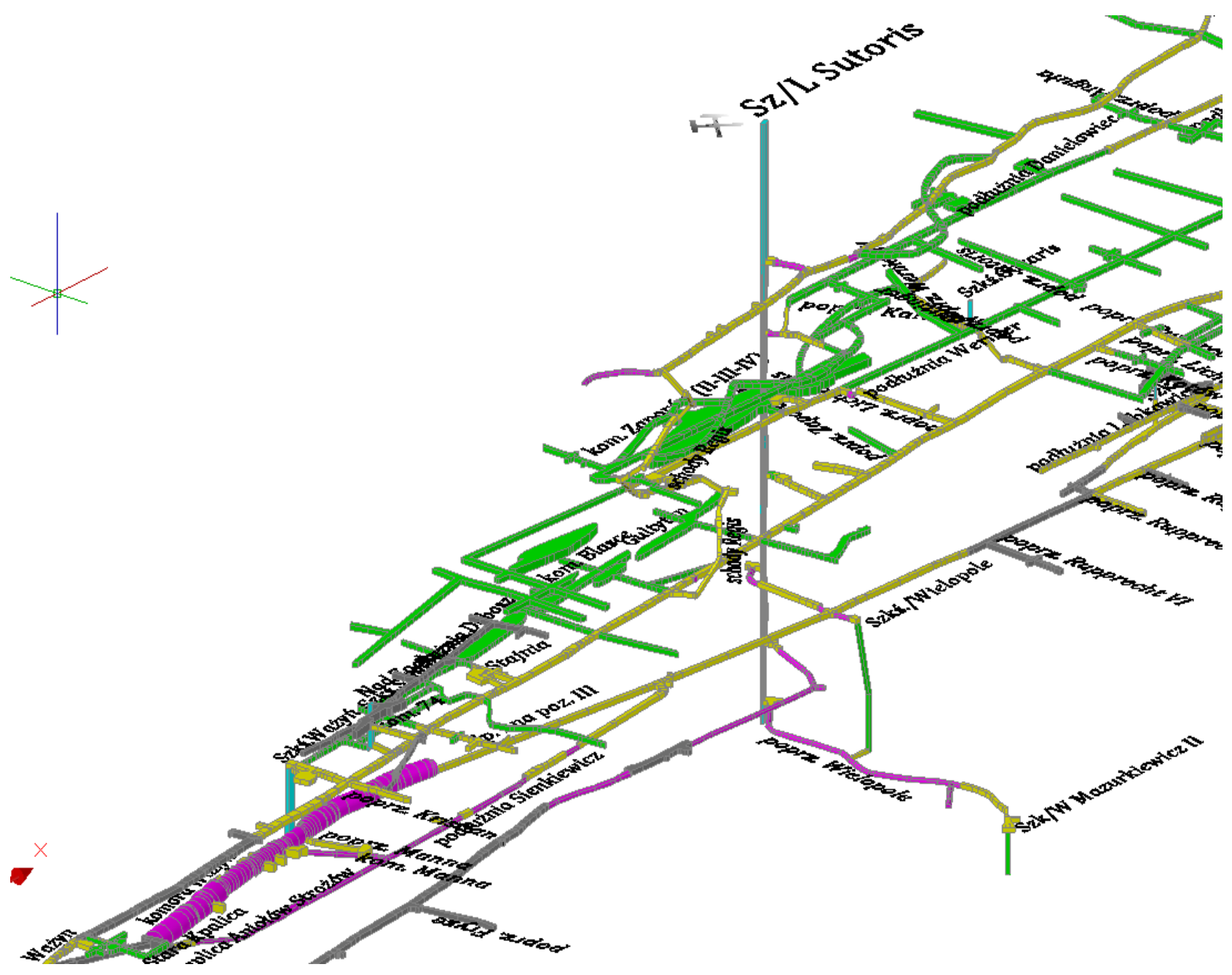

Fig. 5. Spatial visualization of a selected fragment from the central part of the "Bochnia" Salt Mine

Rys. 5. Wizualizacja przestrzenna wybranego fragmentu centralnej części Kopalni Soli „Bochnia”

ment for a full study consisting of a three-dimensional underground mine model (after transforming the model to the PL-2000/7 system) and the surface of the mining area with elements of its development. With such a complicated geometric structure of selected mine elements (e.g. descent), the 3D model ensures transparency and readability of even the most diverse spatial forms of excavations. In addition, the model presented in the article may contribute to the creation of more advanced studies based on modern geodetic and photogrammetric measuring technologies. This means that, unlike analog pseudo-spatial studies built once in axonometric views, it is a fully editable study, easy to geometrically modify and integrate various spatial models (point, framework) regardless of their complexity.

\section{BIBLIOGRAPHY}

D’Obyrn K., Tajduś A. (2017). Geomechanical numerical analysis as a guidance for preservation works of the , Wieliczka” Salt Mine site. Studia Geotechnica et Mechanica, vol. 39, no. 2, pp. 25-34.

Fischer S. (1941). Szkic dziejów bocheńskich salin. Maszynopis. Freudenheim J., Migdas T. (2006). Restrukturyzacja Kopalni Soli „Bochnia”. WARSZTATY z cyklu: Zagrożenia naturalne w górnictwie, Materiały Sympozjum, pp. 597-603.

Garlicki A. (1968). Autochtoniczna seria solna w miocenie Podkarpacia między Tarnowem a Skawina. Biuletyn Instytutu Geologicznego, no. 215, pp. 5-77.

Garlicki A. (1970). Złoże soli kamiennej Moszczenica-Łapczyca na zachód od Bochni. Kwartalnik Geologiczny, vol. 14, no. 2 , pp. 350-360.

Kohonen J., Putkinen N., Laine E.L., Ojala A., Luukas J., Virtasalo J. (2019). Geological Survey of Finland. Steps from 
Seamles Mapping Towards a National Geological 3D-Framework. AER/AGS Special Report, pp. 109-117.

Kortas G., Pałys T., Dudek R. (1993). Pomiar konwergencji w Kaplicy Błogosławionej Kingi w Kopalni Soli Bochnia (opracowanie niepublikowane archiwum KS Bochnia)

Lucas A., Pay D., McClure S., Ribeiro M., Hsu T., Padua P. (2015). The Belmont Mine and an Emerald's Journey from Mine to Market - źródło: GIA Channel.

Kortas G., Szewczyk J., Toboła T. (2004). Ruch górotworu i powierzchni w otoczeniu zabytkowych kopalń soli. Polska Akademia Nauk - Instytut Mechaniki Górotworu. Wydawnictwo Instytutu Gospodarki Surowcami Mineralnymi i Energią PAN, Kraków.

Maciaszek J., Gawałkiewicz R. (2001). Metody przestrzennej wizualizacji wyrobisk górniczych. Materiały Konferencji naukowo-technicznej: VI Dni Miernictwa Górniczego i Ochrony Terenów Górniczych, Ustroń, pp. 289-300.

Maciaszek J., Gawałkiewicz R., Gawałkiewicz I. (2010). Od modelu do numerycznej mapy przestrzennej. Geologia, vol. 36, no. 3, pp. 331-344.

Maciaszek J., Wąsacz W., Szewczyk J. (2015). Mapa górnicza jako element elektroniczny. Przegląd Górniczy, vol. 71 (3), pp. 64-74.

Pitera H., Cyran K. (2008). Zmieniony anhydryt z Kopalni Soli Bochnia. Geologia, vol. 34, no. 1, pp. 5-17.

PN-G-09000-1: 2002. Mapy górnicze. Czesść 1. Podziat i terminologia.
PN-G-09000-3: 2002. Mapy górnicze. Czesść 1. Wymagania podstawowe.

PN-G-09004: 2005. Mapy górnicze. Umowne znaki podziemnych wyrobisk górniczych.

Poborski J. (1952). Ztoże solne Bochni na tle geologicznym okolicy. Biuletyn Instytutu Geologicznego, no. 78.

Shehu A., Lipo S. (2016). 3D modeling and interpretation of $\mathrm{Fe} / \mathrm{Ni}$ deposit in Skroska Mine using Micromine. Albanian Journal of Naturaland Technical Sciences, vol. XXI, pp. 47-60.

Siembab J. (1980). Technologia sporzadzania przestrzennych map wyrobisk górniczych, map pokładów stromo zalegajacych $i$ metod ich reprodukcji. Praca niepublikowana, AGH Wydział Geodezji Górniczej i Inżynierii Środowiska, Kraków.

Rozporządzenie Ministra Środowiska z dnia 28 października 2015 r. w sprawie dokumentacji mierniczo-geologicznej (Dz.U. nr 2015, poz. 1941).

Ustawa Prawo geologiczne i górnicze z dnia 9 czerwca 2011 r. (Dz,U. 2011, nr 163, poz. 981).

Wajs J., Kasza D., Zagożdżon P., Zagożdżon K.D. (2018). 3D modeling of underground objects with the use of SLAM technology on the example of historical mine in Ciechanowice (Otowiane Range, the Sudetes). E3S Web of Conferences XVII Conferences of PhD Students and Young Scientists, pp. 1-10. 